\title{
Financial Sector Development, Trade Openness and Economic Growth Nexus: Evidence from SAARC Countries
}

\author{
Mirajul Haq ${ }^{1}$, Iftikhar Ahmad ${ }^{2}$ and Alyia Jabeen ${ }^{3}$
}

\begin{abstract}
To boost economic growth, SAARC countries resorted to trade liberalization policies since mid-1980s, therefore, now it is high time to evaluate the outcomes of this outward-oriented trade regime. Available literature confined the potential gain with the trading country's status of the financial sector development. This study therefore empirically investigates the complementarity between domestic financial sector and trade openness for its growth effectiveness in the case of SAARC region. The empirical analysis basis upon the panel of six SAARC countries, using panel co-integration technique for the period 1980-2014. The empirical estimates of FMOLS and DOLS indicate that countries holding relatively developed domestic financial sectors enjoy larger gains from trade openness, which finally translates into economic progress. To be exact, the country's domestic financial sector plays a complementary role between openness and growth in SAARC countries. Results hence suggest that SAARC countries need to lay higher emphasis on the development of the domestic financial sector.
\end{abstract}

Keywords: Financial Development, Economic Growth, Trade Openness, SAARC, Panel Co-integration

JEL classification: F10, O40, G10, C23

\section{Introduction}

In received literature, a number of transmission mechanisms are highlighted through which trade openness translates into higher economic growth. Firstly, literature supports the liberal trade regime because it induces competition, which results in efficient resource allocation. Similarly, higher the integration of world markets, greater would be the chances to overcome size constraints, making it possible to secure economies of scale. Likewise, the import of capital goods and machinery supports economic growth by increasing the productivity. Moreover, trade facilitates technological diffusion globally, introducing new technologies among the member countries, which facilitates greater and efficient production. The recent trade models, based on firms' heterogeneity, too point out that trade

\footnotetext{
${ }^{1}$ Assistant Professor, International Institute of Islamic Economics, International Islamic University, Islamabad, Pakistan.

${ }^{2}$ Assistant Professor, Pakistan Institute of Development Economics (PIDE), Islamabad, Pakistan.

${ }^{3}$ Scholar, International Institute of Islamic Economics, International Islamic University, Islamabad, Pakistan.

Corresponding author's Email: iftikhar@pide.org.pk
} 
openness results in reallocation in favour of the most dynamic firm hence gives rise to aggregate productivity growth (Melitz, 2003; Helpman et al., 2004).

In the similar fashion, another stream of literature affiliates the growth and development process to the country's financial development. For instance, in pioneer work on the subject, Bagehot (1873) lay emphasis on the local financial sector for its role in the development and growth process. He derived the argument that easy economic transactions and competitive market mobilization is only possible when a well-established financial sector exists. Schumpeter (1912) extended the idea and reasoned that the financial institutions are very important for growth sustainability as these channelize the financial resource to their most productive uses.

Based on the pioneered work of Bagehot (1873) and Schumpeter (1912), economists developed two different hypotheses concerning the growth effectiveness of the financial system. Firstly, the "demand-led hypothesis" denies the role of finance to boost economic growth, implying that sound financial structure not necessarily causes economic growth (Robinson, 1979). The hypothesis suggests that growth causes the financial sector development instead mainly due to extended demand. Such literature maintains that in response to economic growth, the demand for adequate financial facilities subsequently rises, which results in a greater number of financial organizations, products, and services in the market. Patrick, (1966) further bifurcated the stages and argued that initially the economy utilizes the supply-lead finance, however, the demand-lead finance dominates as growth takes pace. The second strand of literature, the "finance-led hypothesis", was developed and empirically tested by Shaw (1973), McKinnon (1973) and Pagano (1993), among others. As obvious, their findings favour the hypothesis that the financial sector development in a country positively contributes to growth by inducing acceleration in the real sector.

Despite these opposing hypotheses, a consensus is emerging among economists that along with other specific characteristics, the growth effectiveness of trade is also attributed to the financial development of the trading country. Such as, it is widely believed that trade liberalization measures along with welldeveloped local financial sectors reduce inefficiencies in production process, resulting in higher economic growth. It is a recent phenomenon that most of the developing and emerging economies have started putting emphasis on the financial and trade liberalization measures to support higher economic activity.

During their early phases of development, the South Asian economies followed the inward-looking import substitution policies to guard local industries 
from foreign competition and to lower trade deficit. However, regionalism regained its strength against globalization by 1980s, and resultantly South Asian countries moved towards trade liberalization. These countries hence made efforts to follow suit under the banner of SAARC ${ }^{4}$. Since 1980 s, most of the SAARC countries adopted trade liberalization policies to accelerate economic growth, which makes it interesting to investigate whether SAARC countries materialized the potential gain from this outward-oriented trade regime in terms of economic growth. Keeping in view this tendency of outward-oriented trade policies, most recently, some studies investigated trade openness for its effects on the finance-growth nexus and supported the claim (for instance, see Rahman et al., 2015; Asghar and Hussain, 2014; Polat et al., 2014).

However, an alternative stance of studies came with the findings that the sound and efficient financial sector enhances the capacity of outward-oriented trade policies in the long-run growth of the trading countries. This posture of studies has the argument that shallow financial sector surges transaction, monitoring, and information costs, hence reducing the competitiveness of firms in the international market. For instance, Levine (2004) argues that financial development reduces transaction costs, diversifies the risk and consequently increases productivity growth of trading countries. In the same array, most recently Manova (2013) came up with the finding that with the expansion of the local financial sector, credit constraints of firms to enter export markets reduce. Sequentially, this relaxes firms' foreign exchange constraints and hence strengthens the economic growth of trading countries over the long-run. This view maintains the claim that the potential gain of the trade liberalization policies depends on the trading country's domestic financial sector deployment.

Nevertheless, in received literature on the subject, no empirical study has been carried out on the phenomenon in regional context. Therefore, this study attempts to investigate whether local financial sector development plays a complementary role in the growth effectiveness of trade openness by analysing the SAARC region, which has been exercising trade liberalization policies since the 1980s. In this context, following the introduction, Section 2 presents a review of relevant studies. Section 3 explains the methodology adopted for this study, covering theoretical background, empirical model, and estimation technique. Empirical findings are discussed in Section 4. Finally, the last section offers findings and conclusion.

\footnotetext{
${ }^{4}$ SAARC, the regional association of South Asia, was founded on December 08, 1985. Founding members of the organization were Pakistan, India, Bangladesh, Sri Lanka, Bhutan, Nepal, and Maldives. In a recent expansion, Afghanistan also joined SAARC on April 2007.
} 


\section{Literature Review}

Contribution of international trade to growth and development is hotly debated since the second wave of globalization (1985 to present). Previously, many developing countries were following inward-looking import substitution policies on the basis of the infant industry argument. However, the open economy version of the endogenous growth model predicts that international trade stimulates growth through transmission and diffusion of knowledge. For instance, Rivera-Batiz and Romer (1991) argue that trade openness and greater international integration of the developed countries increase growth in all countries. Subsequently, a similar argument was put forth for both the developed and developing countries. Another study states that trade favours transmission and diffusion of information from developed to developing countries, resulting in aggregate productivity growth in less-developed countries (Coe et al., 1997).

A similar argument in favour of openness is that it increases competition and improves allocative efficiency due to the specialization which translates into higher economic growth. Still, empirical studies on trade-growth nexus largely remained inclusive. Some studies did document a positive relationship from openness towards growth. For example, Dollar and Kaaray (2001), Frankel and Romer (1999) and Wacziarg (1998) reports positive effects of trade on growth. Dollar and Kaaray (2004) found that trade openness led to cross country convergence in developing countries.

Nevertheless, some studies provide evidence that openness negatively affects economic growth, particularly in less-developed countries. Greenaway and Sapsford (1994) document evidence that trade openness fails to play any role in economic growth. Similarly, Easterly (2008) document the evidence for the cross country divergence in the case of African countries which implies that trade openness retards the economic growth, particularly underdeveloped countries. Rodick (2001) argues that historical evidence shows that trade liberalization is promoted by those countries which economically grow. On the basis of this controversy, many studies identify the different channel to explain the connection between international trade and economic progress. In line with endogenous growth theory, Haq and Luqman (2014) identified human capital accumulation channel through international trade influences growth in selected countries. More recently, few studies emphasize on the structural features of trading countries for sustainable long run growth. For instance, some studies explore the complementary role of the institutional structure of trading countries in the trade- growth nexus (Matthew and Adegboye, 2014: Rodrik, et al., 2004). 
In similar fashion, some studies emphasize the financial sector development of trading countries for long-run sustainable growth, particularly in less-developed countries. These studies explain that shallow financial sector in developing countries increases transaction, monitoring, and information cost which in turn retard the competitiveness of firms in the international market. Financial development reduces these cost and diversifies the risk which influences investment decisions and aggregate productivity growth (Levine, 2004). Financial deepening also increases allocative efficiency in an economy by directing resources toward productive sectors of the economy.

The growth-finance link is also well researched both in terms of theoretical as well as empirical dimensions. For instance, King and Levine (1993), McKinnon (1973), Goldsmith (1969), Khan and Semlali (2000), Levine et al. (2000), AlYousif (2002), and Kargbo and Adamu (2009), find the evidence of positive contribution to the log run growth process across countries with different socioeconomic characteristics. There are many country-specific studies suggesting a positive association between local financial sector growth and economic progress in different developing countries. For instance, studies on Pakistan (Khan, 2008; Jalil and Feridun, 2011), China (Chang, 2002; Shan and Jianhong, 2006; Cheng and Degryse, 2010; Hye and Dolgopolova, 2011), India (Chakraborty, 2010), Bangladesh (Rahman, 2004; Hossain and Kamal, 2010) ), Ghana (Asante et al., 2011; Adu et al., 2013), Greece (Dritsaki and Dritsaki-Bargiota, 2005; Hondroyiannis et al., 2005), Nigeria (Nurudeen, 2009; Ovat, 2012), Vietnam (Anwar and Nguyen, 2011), Egypt (Abu-Bader and Abu-Qarn, 2008; Bolbol et al., 2005), Malaysia (Ang, 2008), and Korea (Yang and Yi, 2008), document evidence of positive association between economic growth and financial development.

Recently some studies discussed the indirect effect of financial development on growth, i.e., through allocation efficiency and utilization of foreign inflows (Giuliano and Ruiz-Arranz, 2009; Luqman and Haq, 2016; Luqman et al., 2013). Recently some studies investigated the effect of trade, trade integration and liberalization on finance-growth nexus. For instance, Asghar and Hussain (2014) studied how trade openness plugs into the finance-growth nexus for certain developing countries and found that liberalization regime enhances macroeconomic effectiveness of financial development. Similarly, Polat et al. (2014) document the complementary effect of trade liberalization on finance-growth nexus in South Africa. Rahman et al. (2015) investigated the said phenomenon in Australia and found a complementary role of trade in growth-finance nexus. 
Another strand of literature argued that exchange rate management and trade policy, in the existence of shallow financial sector, results in real exchange rate appreciation which subsequently affects export competitiveness and overall macroeconomic performance (Nkusu and Sayek, 2004). Moreover, Manova (2013) argued that financial sector expansion relaxes the credit constraint of firms to enter the export market which in turn relax foreign exchange constraint and amplify longrun growth process in developing countries. Despite the availability of convincing literature on the topic, no study has tested the complementary role of finance in trade-growth nexus. Hence, this study investigates the complementary role of finance in macroeconomic effectiveness of trade openness in the SAARC region.

\section{Methodology}

The methodology section includes three subsections; the first section (3.1) offers the specification of the empirical model. The next section (3.2) shows purposed empirical models and definitions of variables under consideration. Section 3.3 presents estimation techniques.

\subsection{Theoretical Background}

Consider the following Hicks neutral production function with CobbDouglas specification.

$\mathrm{Y}_{\mathrm{t}}=\mathrm{A}_{\mathrm{t}}\left(\mathrm{K}_{\mathrm{t}}\right)^{\beta} \mathrm{L}_{\mathrm{t}}^{1-\beta}$

Where, $Y_{t}$ is the aggregate output is $\mathrm{A}_{\mathrm{t}}$ is technological progress that enters with both traditional factors capital and labour, whereas capital stock and labour are respectively denoted with $\mathrm{K}_{\mathrm{t}}$ and $\mathrm{L}_{\mathrm{t}}$. Thinking through, the complementary role of the financial sector in trade-growth relationship follows the endogenous growth framework. In Equation (1) the non-traditional factor (technological progress $A_{t}$ ) is augmented with financial development $F_{t}$ and trade openness $T_{t}$, taking the form below.

$A_{t}=\phi \cdot T_{t}^{\alpha} F_{t}^{\gamma}$

In Equation (2) $\varphi$ is constant, $T_{t}$ is trade openness, while $F_{t}$ is a measure for financial development. The aggregate production function takes the following form after substituting Equation (2) in Equation (1);

$\mathrm{Y}_{\mathrm{t}}=\phi \cdot \mathrm{T}_{\mathrm{t}}^{\alpha} \mathrm{F}_{\mathrm{t}}^{\gamma} \mathrm{K}_{\mathrm{t}}^{\beta} \mathrm{L}_{\mathrm{t}}^{1-\beta}$

Equation (3) can be modified as follows by taking log;

$\ln \mathrm{Y}_{\mathrm{t}}=\ln \varphi+\alpha \ln \mathrm{T}_{\mathrm{t}}+\gamma \ln \mathrm{F}_{\mathrm{t}}+\beta \ln \mathrm{K}_{\mathrm{t}}+(1-\beta) \ln \mathrm{L}_{\mathrm{t}}$ 
Where $\ln Y_{t}$ is the log of aggregate output that captures with real GDP, $\ln \phi$ the constant term, $\ln _{\mathrm{t}}$ is the $\log$ of trade-openness. Further, financial development is a composite index of three important variables namely domestic credit, money supply (M2) and private credit, which is represented by $\ln F_{t}$. $\ln K_{t}$ is physical capital, and $\ln \mathrm{L}_{t}$ is population growth. Hence, Equation (4) provides us with the foundations to observe the impact of the country's financial sector development on its trade-growth nexus.

\subsection{Empirical Model}

Basing upon the discussion provided above, the empirical models are provided below. Moving logically, our first objective is to analyse trade and study how it affects economic growth in sampled region, hence we empirically test the following base model. The model includes the conventional control variables as well as variables of interest.

$$
\mathrm{LnY}_{\mathrm{it}}=\alpha_{\mathrm{O}}+\alpha_{1} \mathrm{LnTO}_{\mathrm{it}}+\alpha_{2} \mathrm{LnX}_{\mathrm{it}}+\varepsilon_{\mathrm{it}}
$$

Similarly, the second objective is to explore the complementarity between the financial sector and trade-growth tie. Therefore, the interaction term of trade and financial sector advancement $\left(T O_{i t} * F D_{i t}\right)$ is incorporated in the second empirical model. $X_{i t}$ represents control variables like human capital $\left(H C_{i t}\right)$, physical capital $\left(I N V_{i t}\right)$, and population growth $\left(P O P_{i t}\right)$. Human capital $\left(H C_{i t}\right)$ is captured with health expenditure as a percentage of GDP, whereas physical capital $\left(I N V_{i t}\right)$ is captured with investment to GDP ratio. Population $\left(P O P_{i t}\right)$ captures the annual percentage growth in population. Data for variables is obtained from the Economy Watch 2014 and the World Development Indicators 2016.

$$
\operatorname{LnY} Y_{i t}=\beta_{O}+\beta_{1} \operatorname{LnTO}_{i t}+\beta_{2} \operatorname{Ln}\left(\mathrm{TO}_{\mathrm{it}} * \mathrm{FD}_{\mathrm{it}}\right)+\beta_{3} \operatorname{LnX} \mathrm{X}_{\mathrm{it}}+\varepsilon_{\mathrm{it}}
$$

Where $i$ denotes country while $t$ is time dimension. Similarly, $L n$ represents the natural $\log$ of variables. The detailed discussion on variables is given in section 3.3. Thus, the above mentioned empirical models will help to bring to light the effect of the financial sector in the trade-growth relationship using data from six SAARC countries.

\subsection{Estimation Technique}

Here we explain the econometric methodology to look into properties of panel used for analysis. Hence, the panel unit root test provides information on the degree of integration of the data ${ }^{5}$. Once investigated, the long-run relationship is

\footnotetext{
${ }^{5}$ See Appendix A for definition and construction of variables
} 
confirmed through two panel co-integration tests namely Pedroni and Kao Residual. Lastly, FMOLS and DOLS estimation techniques are finally used mainly because of its unbiased estimates and effective t-statistics.

FMOLS was developed by Philips and Hansen (1990) with later development by others including Pedroni (2001). This technique carries asymptotic efficiency by taking into account serial correlation effects and endogeneity, hence it corrects the bias as compared to simple OLS. For heterogeneous panels, the FMOLS is considered the best technique (Hamit and Haggar, 2012). Similarly, the DOLS estimator is attributed to the work of Phillips and Loretan (1991) and Stock and Watson (1993). This technique provides unbiased results in cases where the cointegrating variables are non-stationary. By utilizing the leads and lags of the integrated regressor in the first difference form, DOLS overcomes the small-sample bias and the potential endogeneity (Caballero, 1994).

\section{Empirical Findings and Interpretation}

We explain the results here in three different stages. Firstly, we apply two different tests to check the panel's stationary characteristics. Table 1 exhibits results for IPS as well as Fisher panel unit root tests. Following that, we apply two-panel co-integration tests (Pedrani and Kao Residual), Tables 2, 3 and 4 presents' cointegrations tests result of our purposed specifications. Finally, we estimated our empirical models using FMOLS and DOLS; Table 4 presents FMOLS estimated results, whereas DOLS results are presented in Appendix B.

\subsection{Unit Root Test}

Table 1: Results for ADF Tests

\begin{tabular}{lcccc}
\hline \multirow{2}{*}{ Variable List } & \multicolumn{2}{c}{ Im, Person and Shin W-Stat } & \multicolumn{2}{c}{ Fisher-ADF } \\
& At Level & At First Difference & At Level & At First Difference \\
\hline \multirow{2}{*}{ LnGDP $_{\text {it }}$} & 2.18370 & -10.7789 & 4.40620 & 109.948 \\
& $(0.9855)$ & $(0.0000)$ & $(0.9925)$ & $(0.0000)$ \\
LnTO $_{\text {it }}$ & -1.24947 & -6.87566 & 24.2897 & 119.913 \\
& $(0.1057)$ & $(0.0000)$ & $(0.0423)$ & $(0.0000)$ \\
LnFD $_{\text {it }}$ & 0.91493 & -11.0779 & 12.2538 & 115.045 \\
& $(0.8199)$ & $(0.0000)$ & $(0.5859)$ & $(0.0000)$ \\
LnPOP $_{\text {it }}$ & -2.80684 & -6.87264 & 51.7793 & 292.728 \\
& $(0.0025)$ & $(0.0000)$ & $(0.0006)$ & $(0.0000)$ \\
LnINV $_{\text {it }}$ & -4.76459 & -13.8924 & 50.0280 & 220.623 \\
LnHC $_{\text {it }}$ & $(0.0000)$ & $(0.0000)$ & $(0.0000)$ & $(0.0000)$ \\
& 1.63570 & -11.3323 & 6.64959 & 118.252 \\
\hline
\end{tabular}

The results presented in the Table 1 show that two variables i.e. population

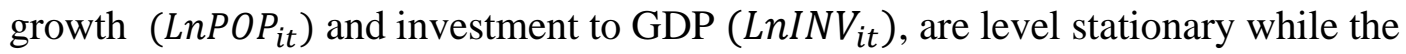
rest are $\mathrm{I}(1)$. In view of the unit-roots tests results, the panel co-integrating relationship is tested using Pedroni Test (2001 and 2004), and Kao Residual Test 
(1999) to investigate the long-run relationship. Table 2 present the result of Pedroni, whereas Table 3 presents Kao tests results.

\subsection{Testing for Co-Integration}

Following the unit root test, we test the presence of co-integration. In this context, Pedroni, and Kao Residual Co-Integration tests have been used. Tables 2 and 3 presents the results of Pedroni and Kao co-integration tests, respectively. Table 2 shows that in all seven specifications the null hypothesis of Pedroni's test i.e. "no co-integration" has been rejected, which points to the long-run relationships flowing from financial development towards the trade-growth relationship. Similarly, the results of Kao residual co-integration test (Table 3) reject the null hypothesis of "no co-integration" which bear out the existence of long-run relationship among variables under consideration.

Table 2: Pedroni's Test for Panel Co-Integration

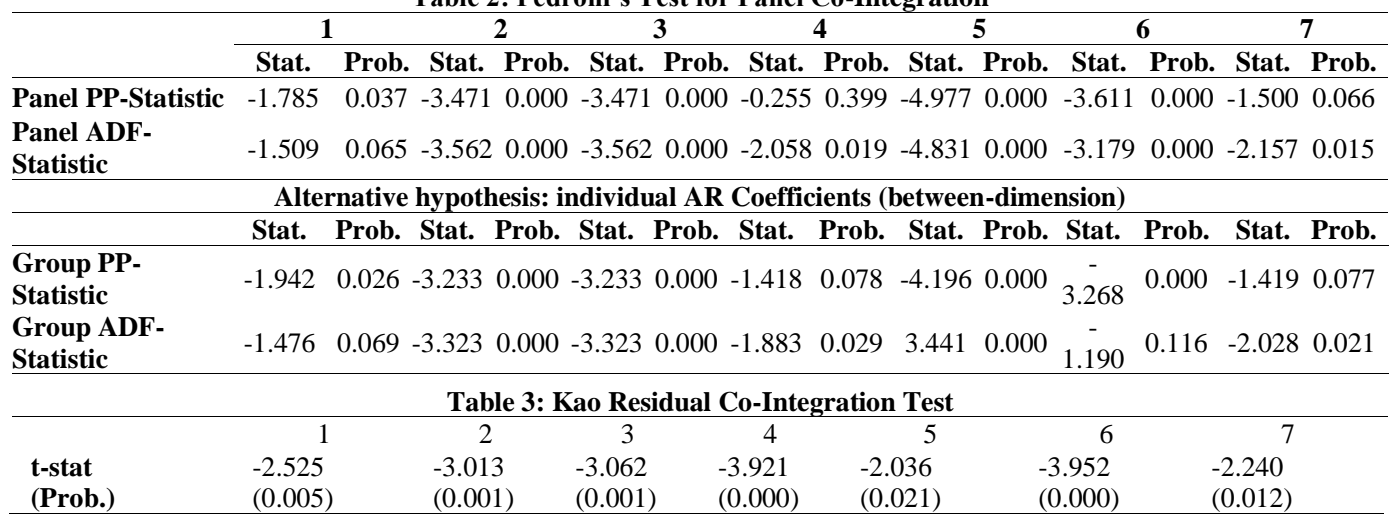

\subsection{Fully Modified OLS Results}

After testing the long-run relationship, coefficients are estimated through FMOLS proposed by Pedroni (1996). The results are presented in Table $4^{6}$ In model 1 , which is the baseline, the variable of interest trade openness $\left(\ln \mathrm{TO}_{\mathrm{it}}\right)$ holds statistically significant and positive coefficient signifying of assistance effect on the dependent variable (i.e., economic growth) of SAARC countries. This confirms the findings of the standard empirical literature on the topic (Rivera and Romer (1991a); Dollar (1992); Grossman and Helpman (1991b and 1991c); Coe and Helpman (1995); Wacziarg and Karen (2008); Das and Paul, 2011; Rizavi et al., 2010; Wacziarg (2001); Mercan et al., 2013) who agree to take the hypothesis that "trade openness is beneficial for economic growth".

\footnotetext{
${ }^{6}$ See results for Panel Dynamic Ordinary Least Square (DOLS) at Appendix B
} 
Table 4: Results for Panel FMOLS

\begin{tabular}{|c|c|c|c|c|c|c|c|}
\hline Variables & 1 & 2 & 3 & 4 & 5 & 6 & 7 \\
\hline LnTO $_{\text {it }}$ & $\begin{array}{c}2.388 * * * \\
(0.000)\end{array}$ & $\begin{array}{c}1.879 * * * \\
(0.000)\end{array}$ & $\begin{array}{l}.824 * * * \\
(0.002)\end{array}$ & $\begin{array}{c}0.861 * * * \\
(0.000)\end{array}$ & $\begin{array}{c}0.683 * * \\
(0.007)\end{array}$ & $\begin{array}{l}0.460 * \\
(0.080)\end{array}$ & $\begin{array}{c}1.474 * * * * \\
(0.000)\end{array}$ \\
\hline $\operatorname{LnPOP}_{\text {it }}$ & $\begin{array}{c}0.902 * * \\
(0.014)\end{array}$ & $\begin{array}{c}1.178 * * * \\
(0.000)\end{array}$ & $\begin{array}{c}1.178 * * * \\
(0.000)\end{array}$ & $\begin{array}{c}1.848 * * * \\
(0.000)\end{array}$ & $\begin{array}{c}2.291 * * * \\
(0.000)\end{array}$ & $\begin{array}{c}1.132 * * * \\
(0.000)\end{array}$ & $\begin{array}{c}1.325 * * * \\
(0.000)\end{array}$ \\
\hline $\operatorname{LnINV}_{\text {it }}$ & $\begin{array}{c}3.525 * * * \\
(0.000)\end{array}$ & $\begin{array}{c}0.544 * * \\
(0.015)\end{array}$ & $\begin{array}{c}0.544 * * \\
(0.015)\end{array}$ & $\begin{array}{c}1.613 * * * \\
(0.000)\end{array}$ & $\begin{array}{c}3.282 * * * \\
(0.000)\end{array}$ & $\begin{array}{c}1.137 * * * \\
(0.000)\end{array}$ & $\begin{array}{c}2.702^{* * * *} \\
(0.000)\end{array}$ \\
\hline LnHC $_{i t}$ & $\begin{array}{c}1.424 * * * \\
(0.000)\end{array}$ & $\begin{array}{c}0.680 * * * \\
(0.004)\end{array}$ & $\begin{array}{c}0.680 * * * \\
(0.004)\end{array}$ & $\begin{array}{c}1.242 * * * \\
(0.000)\end{array}$ & $\begin{array}{c}1.845^{*} * * \\
(0.000)\end{array}$ & $\begin{array}{c}0.853 * * * * \\
(0.000)\end{array}$ & $\begin{array}{c}0.899 * * * * \\
(0.005)\end{array}$ \\
\hline $\operatorname{LnFD}_{\text {it }}$ & -------- & $\begin{array}{c}2.704 * * * \\
(0.000)\end{array}$ & $\begin{array}{c}1.752^{* * * *} \\
(0.000)\end{array}$ & - & & & \\
\hline $\operatorname{LnDC}_{i t}$ & -------- & 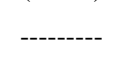 & --------- & $\begin{array}{c}0.846^{* * *} \\
(0.024)\end{array}$ & $\begin{array}{c}0.641 * * \\
(0.051)\end{array}$ & ----- & ----- \\
\hline Ln $\mathrm{PC}_{\mathrm{it}}$ & - & & ---- & -------- & --- & $\begin{array}{c}0.626 * * * * \\
(0.000)\end{array}$ & $\begin{array}{c}0.196 * * * \\
(0.000)\end{array}$ \\
\hline$\left(\mathbf{T O}_{\mathrm{it}} * \mathbf{F D}_{\mathrm{it}}\right)$ & ----- & ------ & $\begin{array}{c}2.820 * * * \\
(0.000)\end{array}$ & ----- & & ----- & \\
\hline$\left(\mathrm{TO}_{\mathrm{it}} * \mathrm{DC}_{\mathrm{it}}\right)$ & -------- & -------- & -------- & ----- & $\begin{array}{c}1.909 * * * * \\
(0.000)\end{array}$ & ------- & -- \\
\hline$\left(\mathbf{T O}_{\mathrm{it}} * \mathbf{P C}_{\mathbf{i t}}\right)$ & -------- & -------- & -------- & -------- & --------- & ---- & $\begin{array}{c}0.994 * * * * \\
(0.000)\end{array}$ \\
\hline
\end{tabular}

Note: P-values are in parenthesis. ***, **, * shows level of significance at $1 \%, 5 \%$, and $10 \%$ respectively

The control variables specified in the standard growth models i.e. human capital $\left(\mathrm{HC}_{\mathrm{it}}\right)$, population growth $\left(\mathrm{POP}_{\mathrm{it}}\right)$ and physical capital $\left(\mathrm{INV}_{\mathrm{it}}\right)$, enters the model significantly, carrying positive sign as per expectation. This points toward the outcomes that all these standard variables signify their effect in the growth of selected SAARC countries. In model 2 , the second variable of concern i.e. $\operatorname{LnFD}_{\text {it }}$ representing financial sector growth, is added as an explanatory variable. This would estimate its direct contribution to the economic growth. The estimated result reveals that country domestic financial sector signifies its role in the growth process, as the financial sector index holds a positive sign that is statistically significant. Among others, these findings are in line with the results of (Gosawami, 2013; Zghidi and Abida, 2014; Sehrawat and Giri, 2016).

To examine the mediating role of the financial sector in trade-growth nexus, this study used the interaction term of trade openness and financial sector development $\left(\mathrm{TO}_{\text {it }} * \mathrm{FD}_{\text {it }}\right)$ as an independent variable. The interaction term holds a statistically significant and positive relationship, showing the complementary role of finance with international trade in long-run growth. Define it compatibly, the country that owns relatively develop financial sector can bring in more from trade openness in terms of growth acceleration.

Onward model 3 we accomplish sensitivity analyses utilizing two proxies of financial sector development and different interaction terms. For instance, we replaced the composed index of the financial sector with the provision of domestic 
credit $\left(\mathrm{LnDC}_{\mathrm{it}}\right)$ as financial sector proxy. Like the index of financial sector development, it enters the model positively and significantly. Similarly, in model 5 we interacted trade openness with the domestic credit provision measure $\left(\mathrm{TO}_{\text {it }} *\right.$ $\mathrm{DC}_{\mathrm{it}}$ ) to have the robustness check. The interaction term enters the model positively that is statistically significant. Results point toward the fact that provision of credit by financial institutions including commercial banks, enhance the capacity of a country to gain more benefits of trade openness in its growth process.

Furthermore, in model 6 the provision of private credit $\left(\mathrm{LnPC}_{\mathrm{it}}\right)$ proxy the financial sector as an explanatory variable. Similar to earlier results, the estimated value of private credit shows its positive and significant response to the growth of the sample countries. Finally, in model 7, the mediator role of financial sector progress in the trade-growth nexus is captured with an interaction term of trade openness and provision of private credit $\left(\mathrm{TO}_{\mathrm{it}} * \mathrm{DC}_{\mathrm{it}}\right)$. In the vein of the previous interaction terms, it enters the model positively and statistically significant, indicating that provision of private credit by financial institution complement the positive effects of trade openness towards growth.

Overall findings of the study demonstrate the outcome that the country's financial sector improvement does play a complementary role in trade-growth nexus in the case of selected SAARC countries. The results put forward the statement that country that own relatively developed domestic financial sector can gain the benefits of outward-oriented trade regime in its economic growth process. The following reasons may explain why. First, Financial development reduces transaction costs, diversify the risk and consequently increase productivity growth of trading countries (Levine, 2004). Second, the country's financial deepening increase allocative efficiency by channelling the resources of firms engaged in international trade towards the most productive sector.

\section{Conclusion}

As deliberated at the start, this study explored the effect of domestic financial sector development on trade-growth nexus. To meet the desired objective, empirical analyses have been carried out for six SAARC countries for the time period 1980-2014. The empirical estimations have been carried out through FMOLS and DOLS estimations techniques. Overall, the study demonstrates that the country's financial sector expansion plays a complementary role in the nexus of trade openness and economic growth, in the case of selected SAARC countries. This indication catches up on the findings that in all three cases, the interaction terms have come up with the desired significant impact. This validates the complementary effect of finance in enhancing the growth effectiveness of trade in 
the case of SAARC countries. The country that owns relatively developed financial sector benefits more from international trade in terms of accelerated growth. Findings suggest, to harness the potential gain of outward-oriented trade regime in term of economic growth, SAARC countries should focus more on the domestic financial sector and its development. 


\section{References}

Abu-Bader, S., \& Abu-Qarn, A. S. (2008). Financial development and economic growth: The Egyptian experience. Journal of Policy Modeling, 30(5), 887898.

Adu, G., Marbuah, G., \& Mensah, J. T. (2013). Financial development and economic growth in Ghana: Does the measure of financial development matter?. Review of Development Finance, 3(4), 192-203.

Al-Yousif, Y. K. (2002). Financial development and economic growth: Another look at the evidence from developing countries. Review of Financial Economics, 11(2), 131-150.

Ang, J. B. (2008). What are the mechanisms linking financial development and economic growth in Malaysia?. Economic Modelling, 25(1), 38-53.

Anwar, S., \& Nguyen, L. P. (2011). Financial development and economic growth in Vietnam. Journal of Economics and Finance, 35(3), 348-360.

Asante, S., Agyapong, D., \& Adam, A. M. (2011). Bank competition, stock market and economic growth in Ghana. International Journal of Business Administration, 2(4), 33-41.

Asghar, N., \& Hussain, Z. (2014). Financial development, trade openness and economic growth in developing countries: Recent evidence from panel data. Pakistan Economic and Social Review, 52(2), 99-126.

Bagehot, W. (1873). Lombard Street: A Description of Money Market (1962 Edition). Homewood: America.

Bolbol, A. A., Fatheldin, A., \& Omran, M. M. (2005). Financial development, structure, and economic growth: The case of Egypt, 1974-2002. Research in International Business and Finance, 19(1), 171-194.

Caballero, R. J. (1994). Small sample bias and adjustment costs. The Review of Economics and Statistics, 76(1), 52-58.

Chakraborty, I. (2010). Financial development and economic growth in India: An analysis of the post-reform period. South Asia Economic Journal, 11(2), 287-308.

Chang, T. (2002). Financial development and economic growth in Mainland China: A note on testing demand-following or supply-leading hypothesis. Applied Economics Letters, 9(13), 869-873. 
Cheng, X., \& Degryse, H. (2010). The impact of bank and non-bank financial institutions on local economic growth in China. Journal of Financial Services Research, 37(2), 179-199.

Coe, D., Helpman. E, \& Hoffmaister, A. (1997). North-South R\&D Spillovers. Economic Journal, 107(440),134-149.

Das, A., \& Paul, B. P. (2011). Openness and growth in emerging Asian economies: Evidence from GMM estimations of a dynamic panel. Economics Bulletin, 31(3), 2219-2228.

Dollar, D., \& Kraay, A. (2001). Trade, growth, and poverty. World Bank, Working Paper, Available at: https://doi.org/10.1596/1813-9450-2615

Dollar, D., \& Kraay, A. (2004). Trade, growth, and poverty. The Economic Journal, 114(1), 22-49.

Dritsaki, C., \& Dritsaki-Bargiota, M. (2005). The causal relationship between stock, credit market and economic development: An empirical evidence for Greece. Economic Change and Restructuring, 38(1), 113-127.

Easterly, W. (2008). Design and reform of institutions in LDCs and transition economies. American Economic Review: Papers \& Proceedings, 98(2), 9599.

Frankel, J. A., \& Romer, D. H. (1999). Does trade cause growth? American Economic Review, 89(3), 379-399.

Goldsmith, R.W. (1969). Financial structure and development. The Economic Journal, 80(318), 365-367.

Goswami, N. (2013). Role of trade openness and financial development in economic growth: Panel evidence from South Asia. International Journal of Trade and Global Markets, 6(3), 301-322.

Greenaway, D., \& Sapsford, D. (1994). What does liberalisation do for exports and growth?. Weltwirtschaftliches Archiv, 130(1), 152-174.

Giuliano, P., \& Ruiz-Arranz, M. (2009). Remittances, financial development, and growth. Journal of Development Economics, 90(1), 144-152.

Hamit-Haggar, M. (2012). Greenhouse gas emissions, energy consumption and economic growth: A panel cointegration analysis from Canadian industrial sector perspective. Energy Economics, 34(1), 358-364. 
Haq, M., \& Luqman, M. (2014). The contribution of international trade to economic growth through human capital accumulation: Evidence from nine Asian countries. Cogent Economics \& Finance, 2(1), 1-13.

Helpman, E., Melitz, M. J., \& Yeaple, S. R. (2004). Export versus FDI with heterogeneous firms. American Economic Review, 94(1), 300-316

Hossain, M. S., \& Kamal, K. M. (2010). Does stock market development cause economic growth? A time series analysis for Bangladesh economy. In International Conference on Applied Economics-ICOAE.

Hondroyiannis, G., Lolos, S., \& Papapetrou, E. (2005). Financial markets and economic growth in Greece, 1986-1999. Journal of International Financial Markets, Institutions and Money, 15(2), 173-188.

Hye, Q. M. A., \& Dolgopolova, I. (2011). Economics, finance and development in China: Johansen-Juselius cointegration approach. Chinese Management Studies, 5(3), 311-324.

Jalil, A., \& Feridun, M. (2011). Impact of financial development on economic growth: Empirical evidence from Pakistan. Journal of the Asia Pacific Economy, 16(1), 71-80.

Khan, M. A. (2008). Financial development and economic growth in Pakistan: Evidence based on autoregressive distributed lag (ARDL) approach. South Asia Economic Journal, 9(2), 375-391.

Khan, M. S., \& Senhadji, A. S. (2000). Financial development and economic growth: An overview. International Monetary Fund, Working Paper, $\mathrm{WP} / 00 / 209$.

Kargbo, S. M., \& Adamu, P. A. (2009). Financial development and economic growth in Sierra Leone. Journal of Monetary and Economic Integration, 9(2), 30-61

Kao, C. (1999). Spurious regression and residual-based tests for cointegration in panel data. Journal of Econometrics, 90(1), 1-44.

King, R. G., \& Levine, R. (1993). Finance, entrepreneurship and growth. Journal of Monetary Economics, 32(3), 513-542.

Levine, R. (2004). Finance and growth: Theory and evidence. NBER, Working Paper, 10766, Available at: http://www.nber.org/papers/w10766.pdf . 
Levine, R., Loayza, N., \& Beck, T. (2000). Financial intermediation and growth: Causality and causes. Journal of Monetary Economics, 46(1), 31-77.

Luqman, M., \& Haq, M. (2016). Contribution of workers' remittances to economic growth in Pakistan: Exploring the role of financial sector development. Migration and Development, 5(1), 37-54.

Luqman, M., Haq, M., \& Lal, I. (2013). Foreign aid and macroeconomic performance in Pakistan: Exploring the role of local financial sector development. Forman Journal of Economic Studies, 9, 109-136.

Mankiw, N. G., Romer, D., \& Weil, D. N. (1992). A contribution to the empirics of economic growth. The Quarterly Journal of Economics, 107(2), 407437.

Manova, K. (2013). Credit constraints, heterogeneous firms, and international trade. Review of Economic Studies, 80(2), 711-744.

Matthew, O., \& Adegboye, F. B. (2014). Trade openness, institutions and economic growth in Sub-Saharan Africa (SSA). Developing Country Studies, 4(8), 18-30.

McKinnon, R. (1973). Money and Banking in Economic Development. The Brooking Institute: Washington DC.

Melitz, M. J. (2003). The impact of trade on intra-industry reallocations and aggregate industry productivity. Econometrica, 71(6), 1695-1725.

Mercan, M., Gocer, I., Bulut, S., \& Dam, M. (2013). The effect of openness on economic growth for BRIC-T countries: Panel data analysis. Eurasian Journal of Business and Economics, 6(11), 1-14.

Nkusu, M. M., \& Sayek, S. (2004). Local financial development and the aid-growth relationship. International Monetary Fund, Working Paper, WP-04-238.

Nurudeen, A. (2009). Does stock market development raise economic growth? Evidence from Nigeria. The Review of Finance and Banking, 1(1), 16-26.

Ovat, O. O. (2012). Stock market development and economic growth in Nigeria: Market size versus liquidity. Canadian Social Science, 8(5), 65-70.

Pagano, M. (1993). Financial markets and growth: An overview. European Economic Review, 37(3), 613-622. 
Patrick, H. T. (1966). Financial development and economic growth in underdeveloped countries. Economic Development and Cultural Change, 14(2), 174-189.

Pedroni, P. (1996). Fully modified OLS for heterogeneous cointegrated panels and the case of purchasing power parity. Manuscript, Department of Economics, Indiana University, 5, 1-45.

Pedroni, P. (2001). Fully modified OLS for heterogeneous cointegrated panels. In Nonstationary Panels, Panel Cointegration, and Dynamic Panels, 15, 93130.

Pedroni, P. (2004). Panel cointegration: Asymptotic and finite sample properties of pooled time series test with an application to the PPP hypothesis. Econometric Theory, 20(3), 597-625.

Phillips, P. C. B., \& Hansen, B. E. (1990). Statistical inference in instrumental variables regression with I(1) processes. The Review of Economic Studies, 57(1), 99-125

Phillips, P. C., \& Loretan, M. (1991). Estimating long-run economic equilibria. The Review of Economic Studies, 58(3), 407-436.

Polat, A., Shahbaz, M., Rehman, I. U., \& Satti, S. L. (2015). Revisiting linkages between financial development, trade openness and economic growth in South Africa: Fresh evidence from combined cointegration test. Quality and Quantity, 49(2), 785-803.

Pradhan, R. P., Arvin, M. B., Hall, J. H., \& Bahmani, S. (2014). Causal nexus between economic growth, banking sector development, stock market development, and other macroeconomic variables: The case of ASEAN countries. Review of Financial Economics, 23(4), 155-173.

Rachdi, H. (2011). The causality between financial development and economic growth: A panel data cointegration. International Journal of Economics and Finance, 3(1), 143.

Rahman, M. H. (2004). Financial development economic growth nexus: A case study of Bangladesh. The Bangladesh Development Studies, 30(3/4), 113128.

Rahman, M. M., Shahbaz, M., \& Farooq, A. (2015). Financial development, international trade, and economic growth in Australia: New evidence from 
multivariate framework analysis. Journal of Asia-Pacific Business, 16(1), 21-43.

Rivera-Batiz, L. A., \& Romer, P. M. (1991). Economic integration and endogenous growth. The Quarterly Journal of Economics, 106(2), 531-555.

Rizavi, S. S., Khan, M. K., \& Mustafa, S. H. (2010). Openness and growth in South Asia. South Asian Studies, 25(2), 419.

Robinson, J. (1979). The Generalization of the General Theory and Other Essay. MacMillan: London.

Rodrik, D., Subramanian, A., \& Trebbi, F. (2004). Institutions rule: The primacy of institutions over geography and integration in economic development. Journal of Economic Growth, 9(2), 131-165.

Schumpeter, J. A. (1912). Theorie der wirtschaftlichen Entwicklung. Leipzig: Duncker \& Humblot. English translation published in 1934, The Theory of Economic Development. Harvard University Press: Cambridge.

Shan, J., \& Jianhong, Q. (2006). Does financial development 'lead' economic growth? The case of China. Annals of Economics and Finance, 7(1), 197216.

Sehrawat, M., \& Giri, A. K. (2016). The impact of financial development on economic growth: Evidence from SAARC countries. International Journal of Emerging Markets, 11(4), 569-583.

Shaw, E. S. (1973). Financial Deepening in Economic Development. Oxford University Press: New York.

Stock, J. H., \& Watson, M. (1993). A simple estimator of cointegrating vectors in higher Order integrated systems. Econometrica, 61(4), 783-820.

Wacziarg, R. (2001). Measuring the dynamic gains from trade. The World Bank Economic Review, 15(3), 393-429.

Yang, Y. Y., \& Yi, M. H. (2008). Does financial development cause economic growth? Implication for policy in Korea. Journal of Policy Modeling, 30(5), 827-840.

Zghidi, N., \& Abida, Z. (2014). Financial development, trade openness and economic growth in North African Countries. Romanian Economic Journal, 17(53), 91-120. 
Financial Sector Development, Trade Openness and Economic Growth Nexus: Evidence from SAARC Countries

\section{Appendix A}

Appendix A: Definition and Construction of Variables

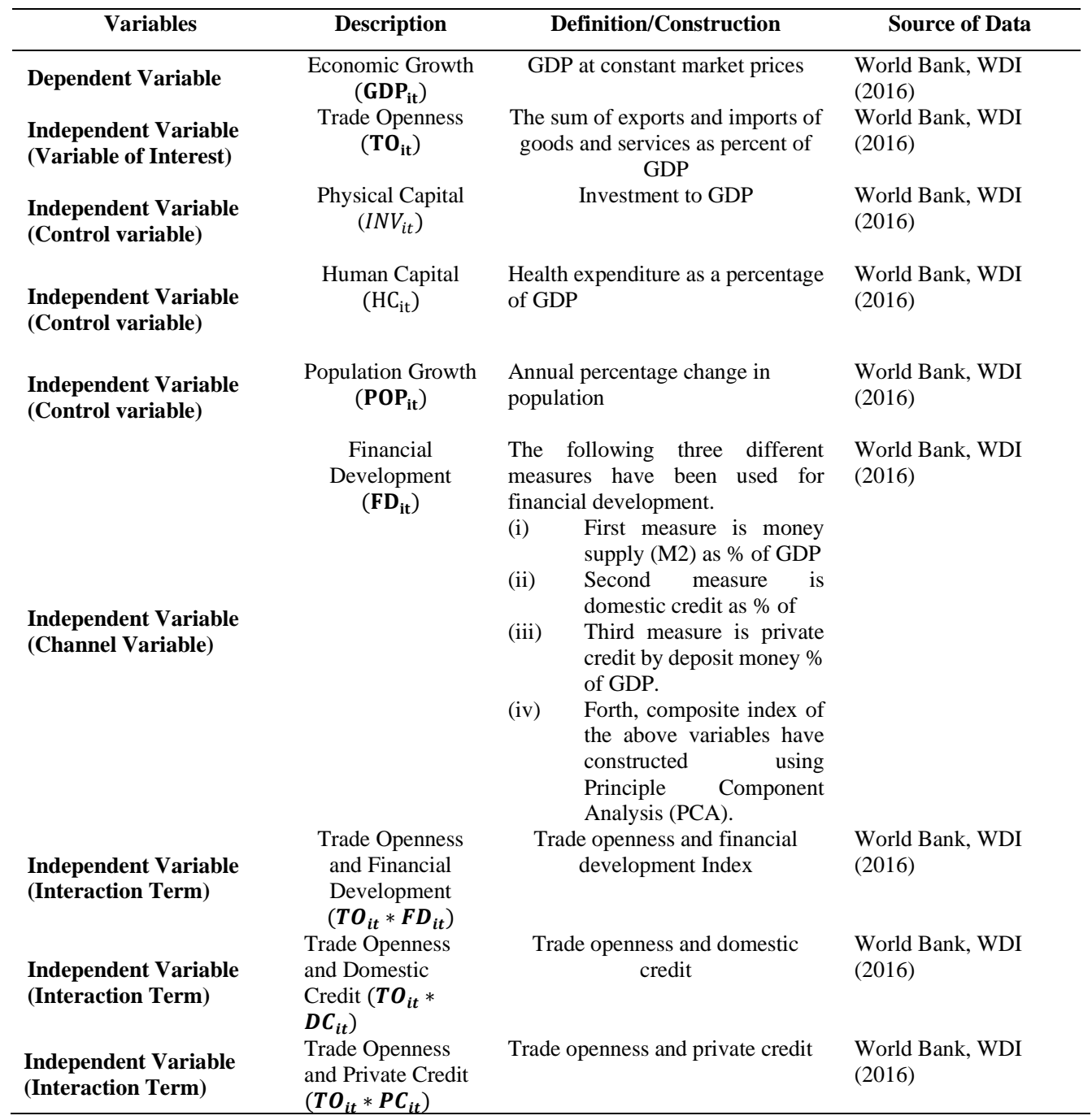




\section{Appendix A}

Appendix B: Panel Dynamic Ordinary Least Square (DOLS)

\begin{tabular}{|c|c|c|c|c|c|c|c|}
\hline Variables & Spec. 1 & Spec.2 & Spec. 3 & Spec. 4 & Spec. 5 & Spec. 6 & Spec. 7 \\
\hline $\operatorname{LnTO}_{\text {it }}$ & $\begin{array}{c}1.744 * * * \\
(0.000)\end{array}$ & $\begin{array}{c}0.952 * * \\
(0.029)\end{array}$ & $\begin{array}{c}1.914 * * * \\
(0.000)\end{array}$ & $\begin{array}{c}1.462 * * * \\
(0.000)\end{array}$ & $\begin{array}{c}1.611^{*} * * \\
(0.000)\end{array}$ & $\begin{array}{c}0.964 * * \\
(0.036)\end{array}$ & $\begin{array}{c}0.991 * * \\
(0.037)\end{array}$ \\
\hline $\operatorname{LnPOP}_{\mathrm{it}}$ & $\begin{array}{c}2.749 * * * \\
(0.000)\end{array}$ & $\begin{array}{c}1.763 * * * \\
(0.008)\end{array}$ & $\begin{array}{c}1.763 * * *( \\
0.008)\end{array}$ & $\begin{array}{c}2.135^{* * * *} \\
(0.000)\end{array}$ & $\begin{array}{c}2.327 * * * * \\
(0.000)\end{array}$ & $\begin{array}{c}1.773 * * * \\
(0.007)\end{array}$ & $\begin{array}{c}1.796^{* * * *} \\
(0.000)\end{array}$ \\
\hline $\operatorname{LnINV}_{\text {it }}$ & $\begin{array}{c}3.292 * * * \\
(0.000)\end{array}$ & $\begin{array}{c}0.595 * * \\
(0.013)\end{array}$ & $\begin{array}{c}0.595^{* * *} \\
(0.013)\end{array}$ & $\begin{array}{c}1.360^{* * * *} \\
(0.002)\end{array}$ & $\begin{array}{c}2.977 * * * * \\
(0.000)\end{array}$ & $\begin{array}{c}1.278 * * * \\
(0.001)\end{array}$ & $\begin{array}{c}2.460 * * * \\
(0.000)\end{array}$ \\
\hline $\operatorname{LnHC}_{\text {it }}$ & $\begin{array}{c}2.468 * * * \\
(0.000)\end{array}$ & $\begin{array}{c}1.750 * * * \\
(0.006)\end{array}$ & $\begin{array}{c}1.750 * * * \\
(0.006)\end{array}$ & $\begin{array}{c}0.251 * * * \\
(0.000)\end{array}$ & $\begin{array}{c}1.517 * * * \\
(0.000)\end{array}$ & $\begin{array}{c}1.840 * * * \\
(0.003)\end{array}$ & $\begin{array}{c}1.831 * * * \\
(0.002)\end{array}$ \\
\hline $\operatorname{LnFD}_{\text {it }}$ & --- & $\begin{array}{c}2.866 * * * \\
(0.000)\end{array}$ & $\begin{array}{c}1.042 * * * \\
(0.000)\end{array}$ & 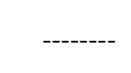 & -4 & 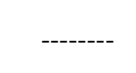 & -------- \\
\hline $\operatorname{LnDC}_{i t}$ & -------- & --- & --------- & $\begin{array}{c}0.361 * * * \\
(0.000)\end{array}$ & $\begin{array}{c}0.220 * * \\
(0.035)\end{array}$ & ---- & ----- \\
\hline Ln $P_{\text {it }}$ & ----- & & ------- & ------ & -- & $\begin{array}{c}0.537 * * * * \\
(0.000)\end{array}$ & $\begin{array}{c}0.216^{* * * *} \\
(0.000)\end{array}$ \\
\hline$\left(\mathbf{T O}_{\mathrm{it}} * \mathbf{F D}_{\mathrm{it}}\right)$ & 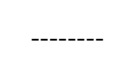 & & $\begin{array}{c}2.931 * * * * \\
(0.000)\end{array}$ & ----- & ------- & -- & - \\
\hline$\left(\mathbf{T O}_{\mathbf{i t}} * \mathbf{D C}_{\mathbf{i t}}\right)$ & ------- & ---- & ------- & -- & $\begin{array}{c}1.143 * * * \\
(0.000)\end{array}$ & -------- & - \\
\hline$\left(\mathbf{T O}_{\mathrm{it}} * \mathbf{P C}_{\mathrm{it}}\right)$ & --- & -------- & -------- & $\cdots$ & --------- & -- & $\begin{array}{c}1.384 * * * \\
(0.000)\end{array}$ \\
\hline
\end{tabular}

Note: P-values are in parenthesis. $* * *, * *, *$ shows level of significance at $1 \%, 5 \%$, and $10 \%$ respectively 